\title{
Review
}

\section{The origins and evolution of the conservation- poverty debate: a review of key literature, events and policy processes}

Dilys Roe

\begin{abstract}
Within the last few years three key concerns have come to dominate the conservation-poverty debate: (1) the activities and accountability of big international conservation NGOs, and their impacts on local communities; (2) the increasingly protectionist focus of conservation policy and the implications for communities resident in and around protected areas, in particular regarding involuntary displacements and evictions; (3) the lack of attention to biodiversity conservation on the development agenda, with the current focus on poverty reduction. The roots of these different strands of the debate lie in much older discussions of the links between environment and development. There have been periods of convergence, especially around issues of sustainable development, participation and decentralization during the 1980s and 1990s. There have also been periods of divergence, in particular the disenchantment with community-based approaches to conservation and the prioritization of poverty over environment, during the 1990s and 2000s. Reactions to the outcomes of the 2003 World Parks Congress brought the three strands of the modern debate to a head. Ongoing discussions around these strands continue at a different pace but the debate appears to be moving fastest on biodiversity's place within the development agenda, although concerns over biodiversity remain marginal compared to the current focus on climate change. But it is within the climate change agenda, and particularly the escalation of discussions around reduced emissions from deforestation, that the next formulations of the conservation-poverty debate are likely to develop.
\end{abstract}

Keywords Biodiversity conservation, climate change, development, environment, poverty reduction.

\section{Introduction}

The role and value of biodiversity, or wild natural 1 resources, in supporting the livelihoods of poor people has been widely debated for over 25 years (Prescott-Allen \& Prescott-Allen, 1982; Scoones et al., 1992; Nasi \& Cunningham, 2001; Rietbergen et al., 2002; Angelsen \& Wunder, 2003; World Resources Institute, 2005; Millennium Eco-

Dilys Roe IIED, 3 Endsleigh Street, London, WC1H 0DD, UK. E-mail dilys.roe@iied.org

Received 13 November 2007. Revision requested 11 January 2008. Accepted 4 March 2008. system Assessment, 2005). There is dispute, however, as to whether conservation of biodiversity can actually lift people out of poverty (World Resources Institute, 2005); act as a safety net, preventing them slipping further into poverty (Angelsen \& Wunder, 2003); or even cause, or exacerbate poverty through the use of strategies such as restrictive protected areas (McShane, 2003; Lockwood et al., 2006) or bioprospecting (Castree, 2003; Swiderska, 2006). This dispute is likely to continue as further evidence is compiled and contested.

Within the last few years, however, the debate on the link between biodiversity conservation and poverty reduction appears to have become more vociferous, and, at times, acrimonious, with three key concerns dominating: (1) The activities and accountability of big international conservation NGOs, and their impacts on local, and particularly indigenous, communities (Bray \& Anderson, 2004; Chapin, 2004; Khare \& Bray, 2004; Romero \& Andrade, 2004; Dowie, 2005). (2) The apparently increasing protectionist focus of conservation policy (Brechin et al., 2001; Wilshusen et al., 2001; Hutton et al., 2005), and the implications for communities resident in and around protected areas, in particular regarding involuntary displacements and evictions (Cernea, 2003; Colchester, 2003; Brockington \& Igoe, 2006). (3) The current lack of attention to biodiversity conservation on the development agenda, with the prioritization of poverty reduction and, particularly, the emphasis on the Millennium Development Goals and on national poverty reduction strategies (Sanderson \& Redford, 2003; Roe \& Elliott, 2004a; Sanderson, 2005; DEG, 2006).

Although these formulations of the conservationpoverty debate have only recently emerged, their roots lie in much older discussions of the links between environment and development. Understanding the origins and evolution of this debate is critical to understanding and resolving the current claims and counter-claims that are being made, and to moving beyond polarizing debate to constructive solutions. The recent focus of the climate change agenda on reduced emissions from deforestation makes this search for solutions particularly important because the proposals for an appropriate mechanism for implementing a suitable reduced emissions strategy have significant implications for conservation and, subsequently, for its impacts on poor and vulnerable people (Griffiths, 2007; Roe et al., 2007). 
Any attempt to condense 50 years of policy discourse will be necessarily simplistic, so this review seeks not to provide a definitive history of this discourse but to: highlight key events, publications and policy narratives within the conservation, development and indigenous rights communities; determine how these influenced the emergence and development of each formulation of the current debate; and consider how this debate could further evolve, or be resolved, in light of the current climate change agenda. The review covers the five major phases that mark significant changes in the debate:

(1) The colonial through to postwar era when 'developed' country agencies first started to intervene in conservation and development policy and practice in developing countries.

(2) The 1970s, when international processes sought to reconcile different priorities over economic development and environmental conservation: first of developed and developing countries, and then of conservation and development communities.

(3) The 1980 s through to mid 199os, when conservation and development policy merged around theories of sustainable development, the role of market forces in natural resource pricing and valuation, decentralization and local participation, and when the indigenous rights movement entered the debate.

(4) The late 1990 s and early 2000s, when a backlash against community-based conservation occurred and development assistance policy switched to focus on poverty reduction and direct budget support.

(5) The period from the World Parks Congress of 2003 to 2006 when the debate, in its current formulations, became particularly public and vociferous.

I conclude by exploring the most recent influences on the debate: an apparent resurgence of biodiversity on the political agenda and a refocusing on ecosystem services, and in particular the links with climate change.

This review draws on an extensive literature review, compiled as part of the process of establishing an international 'learning group' on poverty-conservation linkages, which was entered into a database and used to construct a timeline of key events, publications and policy changes (Fig. 1). It also draws on several histories of conservation (Holdgate, 1999; Brechin et al., 2003; Fortwangler, 2003; Adams, 2004), development (Escobar, 1995; Rist, 2002), and sustainable development (Cross, 2003; IISD, 2006).

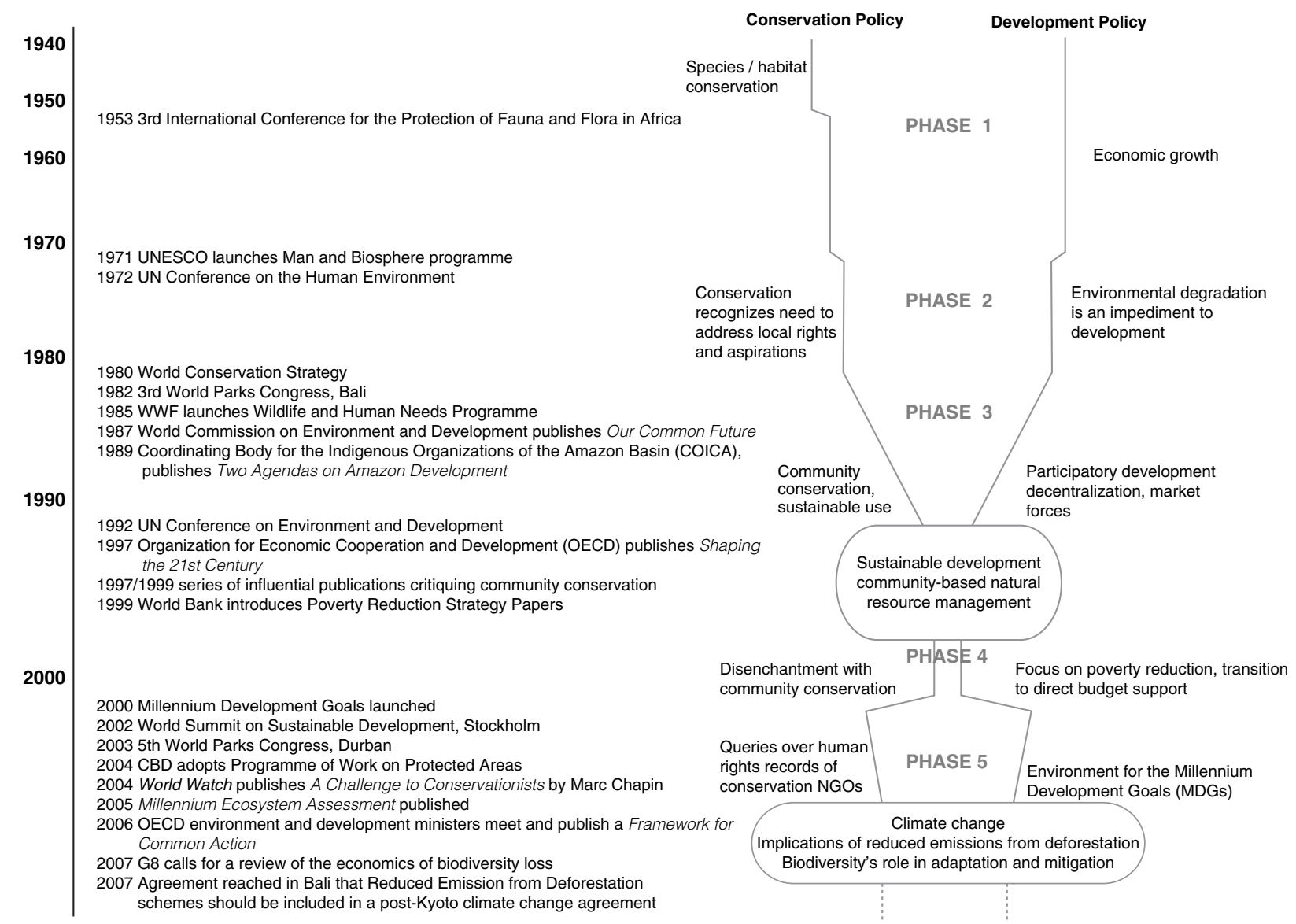

FIG. 1 A timeline of key events and policy processes influencing the development of the conservation-poverty debate, indicating the five phases that mark significant changes in the debate, around which this review is based. 
The term biodiversity conservation is used here because this is the terminology favoured by much of the recent literature covering this debate (Brechin et al., 2001, 2003; Colchester, 2003; Sanderson \& Redford, 2003, Millennium Ecosystem Assessment, 2005). However, this is a relatively new term and, in the context of this paper, is used broadly as a term for the conservation of wildlife, nature or living wild resources. Much of the review focuses on conservation through protected areas because these are the cornerstone of international conservation policy and the protected area approach is the conservation strategy around which much of the debate on poverty impacts has revolved. The term poverty is used in its widest sense, as interpreted by the World Bank (2001), Poverty-Environment Partnership (DFID et al., 2002), and the poor themselves (Naryan et al., 2000), to mean not just lack of income but also lack of civil and political rights, assets and services; i.e. the opposite to the constituents of human well-being as defined by the Millennium Ecosystem Assessment (2005). Hence, the discussions on the links between conservation and indigenous rights are considered here as part of the conservation-poverty debate.

\section{Phase 1 Making international links between conservation and development}

The so-called developed world has long been involved in conservation and development policy-making for implementation in developing countries. During the colonial era several European countries imposed conservation and development policies on their colonies. At that time both sets of policies had the common objective of ensuring the primacy of European colonial interests. Wildlife conservation policy, for example, was primarily focused on protecting species for elite enjoyment by the colonial power, initially for hunting and then for aesthetic enjoyment (Adams, 2004), whilst forest policy concerned itself with protection of timber resources and habitat for wildlife (Grove, 1987; although Grove notes a prescient concern as early as the 1850 s with the link between deforestation and local climatic conditions in Southern Africa's Cape Colony). Meanwhile, development policy sought to promote trade opportunities for the colonial power. For example, the Colonial Development Fund was established under the British Colonial Development Act of 1929 with the intention of developing agriculture and industry in British colonies (Escobar, 1995).

Beyond early and narrow colonial interests, conservation and development organizations that focused their activities overseas were essentially a post-World War II phenomenon. Some international conservation organizations had been established in the late 1800 s and early 1900 . Notable examples include the New York Zoological Society (now the Wildlife Conservation Society) in 1897, the Society for the Preservation of Wild Fauna of the Empire (now
Fauna \& Flora International) in 1903, and the International Council for the Preservation of Birds (now BirdLife International) in 1922. However, despite the formation of an international conservation coalition, now known as IUCN, in 1948, it was the launch of the World Wildlife Fund (now Worldwide Fund for Nature or WWF) in 1962 that marked the start of the international conservation movement as we now know it (Curry-Lindahl, 1978; Holdgate, 1999). Likewise, the 'development age' essentially began with US President Truman's inaugural address in 1949, in which he proposed the concept of 'underdevelopment' and noted the pressing need to do something about it. Thus, the colonial era was seen mainly as a political space in which to expand European empires, whereas the development age was focused on expanding economic space, and raising national incomes became the imperative (Rist, 2002).

Development theory in the 1950 s and 1960 s focused on economic growth, while in rural areas emphasis was placed on agricultural growth based on small-farm efficiency (Ellis \& Biggs, 2001). Anderson \& Grove (1987) noted that, in Africa at least, advisers to postwar colonial governments drew up development plans that had a significant conservation component but biodiversity loss (or the equivalent in the terminology of the day) was not debated by the development sector until the late 1970 s, nor was attention paid to the negative environmental impacts of large infrastructure projects (Sanderson, 2005). Early postwar conservation discourse did make some reference to local development issues, however. The 3 rd International Conference for the Protection of Fauna and Flora in Africa in 1953, for example, emphasized the need for stricter measures to control local hunting but highlighted that this recommendation was in the interests of Africans themselves because fauna was an important food supply (Caldwell, 1954). There were also early moves to provide financial incentives for conservation in Africa through allocation of hunting fees to local councils (Caldwell, 1950; Lindsay, 1987). Nevertheless, not all conservationists were concerned with linking conservation and local benefits. International conservation policy was based on wildlife preservation through the establishment of protected areas that excluded people or, at least, severely restricted their use of wild resources (Adams, 2004). As early as the 1950 s a polarized debate about the purpose of conservation, whether to establish national parks to protect species, or to benefit people, had begun to emerge (FPS, 1958; Holdgate, 1999).

\section{Phase 2 Reconciling different priorities}

\section{Stockholm: linking developed and developing country concerns}

Despite the emerging dispute about the role, and potential social impacts, of national parks (the so-called people and parks debate), some in the international conservation 
community increasingly recognized the importance of balancing nature conservation with human interests. For example, UNESCO launched its Man and Biosphere programme in 1971, in which biosphere reserves acted as 'a bridge between environment and development' (Batisse, 1982). Likewise, IUCN chose Conservation for Development as the theme for its 1972 General Assembly. However, the United Nations Conference on the Human Environment held in Stockholm in 1972 was the first international event that brought together developing and developed country governments with the specific aim of exploring the links between environment and development (Sandbrook, 1984; Strong, 2003).

Although the conference arose from domestic environmental concerns in the North (acid rain in Sweden, marine pollution in Japan; Guha, 1999) the links between environment and development became the dominant theme. Maurice Strong, Secretary General of the Conference noted 'At that time, developing countries were deeply suspicious of the emerging environment issue as a "disease of the rich" that could impose new constraints on their central priority of economic development' (Strong, 2003).

While the Stockholm conference helped promote North-South dialogue on environment-development links, and also to assert the political will of developing countries, it largely failed to foster a shared understanding between environment and development communities, as noted by Strong (1977): 'Conservationists must acknowledge that conservation is as much about people as it is about animals and plants, if not more so. It is not the presence of animals and plants that makes conservation necessary but the presence of people... The proponents of development should recognize that conservation is a prerequisite for development, being the means by which people can make the best use of the living resources on which they depend. But they will not be persuaded of this while conservationists appear to devote themselves to issues for their emotional appeal ...' Shortly after Stockholm a report by the influential Dag Hammarskjöld Foundation presented a critique of development theory as a simple economic process and emphasized the need to take account, inter alia, of basic needs, human rights and ecological limits (Rist, 2002).

\section{The World Conservation Strategy: bridging the conservation-development divide}

Although attempts continued throughout the 1970 s to promote environment-development links (Dasmann et al., 1973; Poore, 1976) it was the World Conservation Strategy, published by IUCN, the UN Environment Programme (UNEP) and WWF (IUCN et al., 1980) that was the first influential document produced by conservationists to bridge the conservation-development divide (Robinson, 1993). The Strategy highlighted both the potential synergies and trade offs between conservation and development and echoed Strong's (1977) concerns about the ideological chasm between practitioners. The Strategy also saw conservationists as being partly to blame for this chasm '... by allowing themselves to be seen as resisting all development... The end result has not been to stop development but to persuade many development practitioners, especially in developing countries, that conservation is not merely irrelevant but harmful and antisocial' (IUCN et al., 1980).

The World Conservation Strategy attempted to address the apparent disconnect between conservation and development by emphasizing the potential links and proposing that the two were not necessarily mutually exclusive. Hence, the Strategy coined the term sustainable development as a process in which conservation and development were mutually interdependent (Robinson, 1993). This thinking on the essential linkages between conservation and development represented a new departure at the time. It also showed many conservationists and development practitioners how divided their different worlds had become (Talbot, 1980).

The World Conservation Strategy also represented another milestone in the conservation-poverty debate by making the first links between poverty and ecological impacts. Where earlier documents had focused on environmental degradation as a result of economic development processes, the Strategy proposed that much habitat destruction and overexploitation of living resources by individuals, communities and nations in the developing world was a response to relative poverty (IUCN et al., 1980). This link between poverty and ecological degradation was reiterated in the Global 2000 Report (CEQ, 1981) that presented scenarios for the world in the year 2000 based on trends in the 1960s and 1970s.

\section{Phase 3 Merging conservation and development agendas}

The ascent of indigenous rights

In the 1960s and throughout much of the 1970 s there was little interaction between conservationists and indigenous peoples. In Latin America, for example, the large conservation NGOs tended to work through urban-based local groups and showed little awareness of indigenous peoples (Chapin, 2004). However, the 1980 s witnessed an increased focus on human rights within the conservation movement, particularly on indigenous rights and in relation to displacement from protected areas. The IUCN General Assembly in 1975 had already adopted a Recommendation that indigenous peoples' rights should be taken into account in national parks and other protected areas (Holdgate, 1999). This Zaire Resolution was reaffirmed and strengthened at the third World Parks Congress in Bali 
in 1982, which advocated the implementation of joint management arrangements between societies that have traditionally managed resources and protected area authorities (Colchester, 2004). The development sector also mirrored the conservation movement in paying attention to indigenous rights during the 1980 (Goodland, 1982).

Recognizing this emerging interest, an indigenous peoples' organization, the Coordinating Body for the Indigenous Organizations of the Amazon Basin (COICA), produced the key text of the period, on indigenous rights and the links with both conservation and development. Two Agendas on Amazon Development (COICA, 1989) addressed both conservation and development practitioners. Part One, aimed at the development community, called for recognition of indigenous peoples' rights and the need for prior informed consent in any development intervention; it also called for small-scale, locally controlled initiatives as the basis for future Amazonian development. Part Two, To the Community of Concerned Environmentalists, acknowledged the role of the international conservation community in rainforest conservation but expressed concern over their preoccupation with wildlife over and above local communities. The statement then proposed a closer working relationship between conservation organizations and indigenous groups.

Two Agendas on Amazon Development generated much discussion about partnerships, alliances, co-management of protected areas, participatory management, and a variety of other working relationships (Chapin, 2004). Following its publication, COICA invited 12 environmental groups to the First Summit Between Indigenous Peoples and Environmentalists in Iquitos, Peru, in 1990. The resultant Iquitos Declaration confirmed the importance of recognizing indigenous land rights and proposed an alliance that was subsequently established as the Coalition in Support of Amazonian Peoples and Their Environment (Amazon Alliance, undated). In the meantime, a flurry of exchanges appeared in the conservation literature on the role of indigenous people in conservation and on some of the apparent contradictions between indigenous values and international conservation priorities (Redford, 1990; Alcorn, 1993; Redford \& Stearman, 1993).

The attention paid to the relationship between indigenous people and conservation organizations was not limited to the Amazon. The International Alliance of Indigenous and Tribal Peoples of the Tropical Forests was founded in 1992, with members from all parts of the tropics. The founding of the Alliance was marked with the adoption of a Charter that included a number of articles relating to biodiversity and conservation, including: 'Conservation programmes must respect our rights to the use and ownership of the territories and resources we depend on. No programmes to conserve biodiversity should be promoted on our territories without our free, prior and informed consent as expressed through our indigenous organizations' (International Alliance, 1992).

\section{Participation, conservation and communities}

The 1980s also saw increased recognition of the need to ensure benefits for local people from conservation. In some areas, however, this recognition was already well entrenched; revenue sharing, for example, had been implemented in Zimbabwe by the mid 1970 (Child, 2003). The Bali Action Plan, an outcome of the 3rd World Parks Congress in 1982, was described as a 'revolutionary advance in linking the conservation of protected areas with social and economic development' (McNeely \& Miller, 1982). This congress was seen by some as a turning point in conservation practice, through its encouragement of local participation and sustainable use (Wilshusen et al., 2003).

In 1985 WWF recognized the need to take poverty and local economic development around protected areas seriously, with the launch of its Wildlife and Human Needs Programme. The Programme comprised 20 projects that sought to combine conservation and development in developing countries. Other Integrated Conservation and Development Projects or community wildlife management programmes were also implemented at this time, most notably in Southern Africa, including the Communal Areas Management Programme for Indigenous Resources (CAMPFIRE) in Zimbabwe and the Luangwa Integrated Resource Development Programme in Zambia. Among development practitioners, Care International was unusual in also recognizing the potential of an integrated approach, launching its Development Through Conservation initiative in Uganda in 1988. Reflecting this mood of integration, Conservation in Africa (Anderson \& Grove, 1987b) was a key text of the time, and brought a social science perspective to what had previously been essentially a biologist's agenda.

Development theory in the 1980 s was also emphasizing the need for local participation (Ellis \& Biggs, 2001), notably in texts on rural development that emphasized decentralization and local empowerment (Chambers, 1981, 1983, 1987). Structural adjustment policies that characterized the 1980 also emphasized deregulation and decentralization, thus adding impetus to participatory approaches. This theory and practice of participation provided the driving force for the convergence of conservation and development discourses that lay behind the rise of the community conservation paradigm (Adams, 2004). In particular, it created an opportunity for conservation organizations to tap into aid budgets as a new source of funding.

Overall, the late 1980s and early 1990s was a period when both conservation and development communities adopted participatory approaches to resource management, whether labelled as Integrated Conservation and Development 
Projects, community-based natural resource management, community conservation or otherwise, with zeal (Hulme \& Murphree, 2001). For example, the World Bank published Living with Wildlife (Kiss, 1990), the UK Overseas Development Administration (now Department for International Development) commissioned a review of participatory approaches to wildlife management to inform its new African wildlife policy (IIED, 1994), and many government and non-government conservation bodies experimented with various approaches (Western \& Wright, 1994).

\section{Sustainable development and sustainable use}

Community conservation was seen by Campbell \& VainioMattila (2003) as one of the manifestations of the gradual merging of conservation and development narratives around the theory of sustainable development. The emphasis of the World Conservation Strategy on sustainable development had also elevated conservation on the donor agenda (Borgerhoff Mulder \& Coppolillo, 2005). The Strategy spawned a series of National Conservation Strategies, the first in a series of different types of country-level environmental plans supported by development agencies (Robinson, 1993).

Nevertheless, there was some frustration that little was being achieved beyond policy rhetoric (Sandbrook, 2003). To address this, a World Commission on Environment and Development was established in 1982 to develop a longterm agenda for action. The main outcome of the so-called Brundtland Commission was the report Our Common Future (WCED, 1987). This popularized the term sustainable development and laid the groundwork for a UN Conference on Environment and Development in 1992. As one of its major outputs, the Rio Earth Summit produced Agenda 21, which for the first time tied problems together and gave some direction for comprehensive global solutions (IISD, 2002).

During the same period IUCN, UNEP and WWF published a follow-up report to the World Conservation Strategy, Caring for the Earth (IUCN et al., 1991). Some saw this as an attempt to 'graft the ideas of sustainable development back onto a conservation agenda' and that the resulting document was an uneasy hybrid that subsumed conservation under the development agenda and confused the distinct goals of conservation and development (Robinson \& Redford, 2004). Robinson \& Redford (2004) further noted that 'It is this confusion that forms the intellectual antecedents of ICD [Integrated Conservation and Development] efforts'.

Caring for the Earth did, however, place emphasis on sustainable use as a strategy for conservation, reflecting the objectives of the Convention on Biological Diversity (CBD), another of the outputs of the Earth Summit, and also creating synergies with the increasing emphasis in development circles on market mechanisms. Hutton et al. (2005) described how the market was a central feature of overseas aid policy in the early 1990s. Not only does the CBD emphasize sustainable use and benefit sharing alongside conservation, the preamble includes a specific reference to poverty, noting that economic and social development and poverty eradication are the first and overriding priorities of developing countries (United Nations, 1992).

\section{Phase 4 The shift to poverty reduction and the resurgence of protectionism}

\section{From participation to protection?}

Enchantment with integrated conservation and development and community conservation was short-lived amongst many conservationists. Despite the conceptual strides made in the 1980 s and early 1990 s in linking conservation and local benefits, especially with regard to protected areas, the people and parks debate continued as an undercurrent (Rao \& Geisler, 1990; West \& Brechin, 1991).The debate took on a new dimension in the late 1990s, however, when it changed from simply arguing for and against protected areas to critiquing the success, or otherwise, of community-based or integrated approaches (Kramer et al., 1997; Brandon et al., 1998; Oates, 1999; Terborgh, 1999). Wilshusen et al. (2001) and Brechin et al. (2001) detailed this critique, noting two main messages: that community participation is a noble goal but channels funding away from conservation, and that it has minimal effect on biodiversity protection. Consequently, conservation strategies should stop attempting everything and focus on the core goal of biodiversity protection.

Hutton et al. (2005) correlated this backlash with a parallel trend among development assistance agencies away from funding community-based approaches and towards alternative conservation strategies that included landscape-level approaches and payments for environmental services. In Europe, however, the shift can be traced to changes in development policy discourse and in aid architecture as much as to disillusionment with community conservation (Roe \& Elliott, 2004b).

\section{The poverty priority}

Poverty reduction has been a recurring theme within the international development agenda (Maxwell, 1999). However, it only became the priority focus of development assistance policy in the late 1990s, for two main reasons. Firstly, the Development Assistance Committee of the Organization for Economic Cooperation and Development (OECD) published its report Shaping the 21st Century in 1996 (OECD, 1996). This included seven international 
development targets that reflected commitments made at various UN summits since the 1970 (Satterthwaite, 2003). Consequently, many bilateral aid agencies shifted their policies in line with these targets. For example, the UK Department for International Development published a White Paper on poverty reduction (DFID, 1997). The United Nations repackaged these international development targets in 2000 as the Millennium Development Goals, gaining an unprecedented level of international commitment to poverty reduction (Satterthwaite, 2003).

Secondly, the World Bank and International Monetary Fund initiated the development of country-level Poverty Reduction Strategy Papers in 1999 as the basis for concessional lending and debt relief to poor countries. These were underpinned by the Comprehensive Development Framework that emphasized developing country ownership and direction of the development agenda (Stiglitz, 1998). This had a significant impact on the delivery of development assistance funds, with many donor agencies moving away from project-based funding and towards direct budget support. Under this, aid money is paid to the recipient country treasury and the government decides on its allocation in line with the priorities identified in its poverty reduction strategy. Consequently, development assistance funding that had previously been made available for biodiversity conservation projects by donor countries was significantly reduced, unless identified as a priority by recipient countries (Roe \& Elliott, 2004b).

\section{A new strand to the conservation-poverty debate}

This shift in aid policy and process stimulated a concern that biodiversity had 'fallen off' the development agenda and that, simultaneously, the conservation agenda had been burdened with poverty reduction (Redford \& Sanderson, 2002). This argument emerged at the 2002 meeting of the Society for Conservation Biology and was aggravated by a speech by the UK Minister for International Development, who highlighted the so-called bushmeat problem in terms of its implications for poor peoples' livelihoods (Short, 2002). Consequently, the conservation literature soon carried articles critiquing the assumed links between bushmeat consumption and poverty (Robinson \& Bennett, 2002), and the overall emphasis of development policy on poverty reduction at the expense of attention to conservation objectives (Sanderson \& Redford, 2003).

The World Summit on Sustainable Development was also held during 2002, in Johannesburg. Biodiversity was included as one of five priority issues but the main outcomes of the Summit, the Johannesburg Declaration on Sustainable Development (United Nations, 2002a) and the Johannesburg Plan of Implementation (United Nations, $2002 b)$ both highlighted poverty reduction as the overarching priority for sustainable development. The Plan of
Implementation states that reversing the trend in biodiversity loss will only be achieved if local people benefit from the conservation and sustainable use of biological diversity (United Nations, 2002b). The 2010 biodiversity target adopted by the 7 th Conference of Parties to the CBD in 2002, and endorsed at the World Summit, also emphasized poverty reduction. The first, and commonly quoted, phrase of the target is to achieve by 2010 a significant reduction of the current rate of biodiversity loss. However the second, but often overlooked, phrase is 'as a contribution to poverty alleviation and to the benefit of all life on earth.' The World Summit on Sustainable Development process also irritated conservationists, who commented that the sustainable human-nature interactions proposed at Rio had been hijacked by the development agenda, abandoning any linkage between human concerns and nature conservation (Sanderson, 2005).

\section{Phase 5 Mainstreaming the conservation- poverty debate}

\section{A new paradigm for protected areas?}

The 5th IUCN World Parks Congress was held in Durban, South Africa in 2003, 1 year after the World Summit on Sustainable Development, and attracted an unprecedented attendance of indigenous and local community groups and representatives. Until this point, the various guises of the conservation-poverty debate had been a mere undercurrent within mainstream conservation and development discourses. The Congress marks the point at which the debate went mainstream. With the theme Benefits Beyond Boundaries, the Congress produced a wealth of recommendations on indigenous rights, poverty and governance, and resulted in the Durban Accord, which announced a so-called new paradigm for protected areas in which conservation goals were equitably integrated with the interests of all affected people (IUCN, 2003a). It also resulted in the Durban Action Plan, which included targets to ensure protected areas strive to alleviate poverty and in no case exacerbate poverty, and that all existing and future protected areas should be managed and established in full compliance with the rights of indigenous and mobile peoples and local communities (IUCN, 2003b).

The following year the 7 th Conference of Parties to the CBD adopted an ambitious Programme of Work on Protected Areas, including a stream on equity, governance and benefit sharing. Coupled with the developments at the World Parks Congress, some celebrated this as heralding a new paradigm in participatory conservation (Phillips, 2003; Balasinorwala \& Goyal, 2004). Equally, these developments added fuel to the fire of those commentators concerned that the conservation agenda was being hijacked (Terborgh, 2004; Oates, 2006). 


\section{Conservation under public scrutiny}

Following its mainstreaming at the 2003 World Parks Congress, the conservation-poverty debate went public in 2004 with the publication of $A$ Challenge to Conservationists (Chapin, 2004). Although not about poverty per se, this article critiqued the activities of three large international conservation NGOs, particularly for their attitudes to, and impacts on, indigenous people. Whilst widely criticized for factual inaccuracies, Chapin (2004) opened out debate and stimulated a huge volume of responses from both conservation and indigenous peoples' organizations (Worldwatch Institute, 2005a,b).

No sooner had the debate quietened, when the popular media published another conservation 'scandal' that documented forced evictions from protected areas (Dowie, 2005). This article was also widely criticized for inaccuracies but nevertheless brought this issue to public attention and was followed by many academic writings on the subject (Brockington \& Igoe, 2006; Igoe, 2006; West et al., 2006).

\section{Future directions: conservation, poverty and climate change}

There have been periods of convergence in the evolution of the conservation-poverty debate as it has moved towards its present formulations, especially around issues of sustainable development, participation and decentralization during the 1980 s and 1990s. There have also been periods of divergence, in particular the disenchantment with community-based approaches to conservation and the prioritization of poverty over environment during the 1990s and 200os. Fig. 2 summarizes the key themes of the debate since 1950. Reactions to the outcomes of the 2003 World Parks Congress brought the three strands of the debate to a head. However, ongoing discussions around these strands continue at a different pace.

On NGO accountability, a number of leading conservation NGOs are pursuing internal, and sometimes public, deliberations about the extent of their accountability to local communities and their role in addressing socioeconomic issues (Walpole, 2006; Redford \& Fearn, 2007). The mission statements and public policy statements on the websites of most of the international conservation organizations show increasing attention to local livelihood issues, indigenous rights, and poverty (Roe \& Walpole, in press).

On protectionism and displacement from protected areas, the people and parks debate is ongoing in both the conservation and development literature (Brockington et al., 2006; Cernea \& Schmidt-Soltau, 2006; Rangarajan \& Shahabuddin, 2006; Wilkie et al., 2006). However, there are moves to develop more collaborative processes to understand better the nature and scale of protected area impacts through international processes that shape the protected areas agenda, including the CBD, IUCN congresses and Global Environment Facility strategic objectives. Increasing efforts are also being made to understand better the spatial linkages between protected areas and poor people (Redford et al., 2008; de Sherbinin, 2008; Upton et al., 2008).

The debate is now moving fastest, however, on the place of biodiversity within the development agenda, and biodiversity seems to be enjoying a resurgence on the political agenda: the Millennium Ecosystem Assessment highlighted the role of biodiversity in underpinning the delivery of a range of ecosystem services upon which long-term human well-being depends (Millennium Ecosystem Assessment, 2005). The OECD countries' environment and development ministers met in 2006 for the first time since 1991. The resultant Framework for Common Action Around Shared Goals emphasized the centrality of environment in meeting the Millennium Development Goals. Biodiversity was specifically mentioned in the context of identifying and developing policies and instruments for better integration of global environmental objectives into national and local development plans and policies (OECD, 2006). The European Commission adopted a communication on Halting the Loss of Biodiversity by 2010-and Beyond, with an Action Plan including detailed measures for mainstreaming biodiversity in EU and member states' development assistance programmes (Commission of the European Communities, 2006). The Norwegian Ministry of Foreign Affairs produced a new action plan for development cooperation which emphasized that environmental concerns should become integral to all development cooperation, and prioritizing biodiversity as a major focus for Norwegian funding (Government of Norway, 2006). IUCN hosted an international conference on Biodiversity in European Development Cooperation that brought renewed calls to mainstream biodiversity into development assistance (Council of the European Union, 2006; IUCN, 2006). The German Presidency of the G8 included a call for a biodiversity review $(G 8,2007)$ along the lines of the Stern Review of the economics of climate change (Stern, 2006).

Despite this apparent resurgence, concerns over biodiversity remain marginal compared to the current focus on climate change. But it is within the climate change agenda that the next formulations of the conservationpoverty debate are likely to develop. The Intergovernmental Panel on Climate Change recently concluded that the resilience of many ecosystems is likely to be exceeded this century as a result of global warming and related climate impacts such as wildfires and floods. At the same time, it is likely to be the poorest communities in the poorest countries who are hit the hardest, as a result of their geographic location, their vulnerability to environmental hazards and their direct reliance on ecosystem services (IPCC, 2007). 
1950s 1960s 1970s

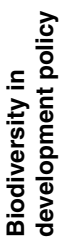

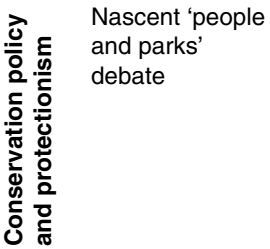

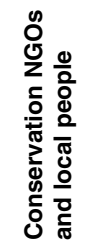

between 1980s

Little interaction UN Conference on World

between Human Environment Conservation

conservation and links environment Strategy links

and development

Strategy links

development, plus

poverty and

ecological impacts

1990s

Rio Earth Summit Development policy easserts notion of starts to prioritize sustainable development poverty reduction

$\begin{array}{ll}\begin{array}{l}\text { Man and } \\ \text { biosphere }\end{array} & \begin{array}{l}\text { Protected area management linked } \\ \text { with local development }\end{array} \\ & \begin{array}{l}\text { Emphasis on participation in } \\ \text { conservation and development } \\ \text { discourse. Launch of ICDPs and } \\ \text { community-based conservation }\end{array}\end{array}$

Increasing assertion and recognition of indigenous rights

IUCN pays attention to links

Partnerships between

local communities and conservation managers

Debate on

'conservation ethic'

communities

indigenous rights
ind
Conservationists Centrality of

Climate change

biodiversity has MDGs

$\begin{array}{ll}\text { 'fallen off' } & \text { re-emphasized } \\ \text { development } & \end{array}$

agenda

supercedes all

other

environmental

issues on

development

agenda

Discussions around avoided eforestation highlight

Critiques of International protected

community-based and area policy emphasizes

integrated approaches; governance, poverty,

$\begin{array}{ll}\text { integrated approaches; } & \text { governance, pove } \\ \text { resurgence of increased indigenous rights }\end{array}$

protectionism

Popular and academic

literature highlights

problem of displacement

from protected areas

implications for

indigenous and

local community

rights as well as

for the future of

protected areas,

and link

conservation and

development

concerns

Internationa

Conservation

conservation NGOs organizations pay

criticized for impacts on increasing attention to

local people issues of accountability,

indigenous rights and poverty

FIG. 2 The emergence and convergence, since the 1950s, of the three current strands of the conservation-poverty debate. 
Biodiversity conservation both affects and is affected by climate change. On the one hand, biodiversity can help poor people adapt to, and mitigate the effects of, climate change: for example, through natural protection against floods and increased resilience provided by diverse traditional crops (Reid \& Swiderska, 2008). On the other hand, because of the potential threats to biodiversity posed by climate change, there are calls for renewed support for, and expansion of, protected areas (Hansen et al., 2003). Discussions around reduced emissions from deforestation also have implications for protected areas (Roe et al., 2007). Consensus was reached at the most recent Conference of Parties of the UN Climate Convention that a post-Kyoto agreement must include measures seeking to reduce deforestation in tropical countries (Horowitz \& O'Sullivan, 2008). Nevertheless, concerns have been raised over the potential implications of reduced emissions from deforestation schemes on local communities (Griffiths, 2007): renewed or increased top-down approaches to forest conservation, including exclusionary models such as strictly protected areas with no human habitation; unjust targeting of local communities as drivers of deforestation; land speculation, land grabbing and land conflicts; violations of customary land and territorial rights; corruption and embezzlement of international funds by national elites; and inequitable and abusive community contracts.

Each of these concerns has previously featured in the evolution of the conservation-poverty debate. Has the debate therefore really evolved or is it simply running in a circle? While revisiting many common themes, the climate change agenda brings a new dimension to the discussion: both conservation and development agencies share mutual and vested interests in ensuring the development of effective strategies to mitigate climate change. The alternative is to risk the undermining of investments in both conservation and poverty reduction, because climate change affects both agendas. After more than 50 years of debate, climate change may, therefore, be the glue that binds the conservation and development communities together and invigorates a timepressured search for sustainable solutions.

\section{Acknowledgements}

This article benefited from a detailed review by Nigel Leader-Williams, and comments from Lisa Campbell and two anonymous reviewers. Joanna Elliott contributed to a preliminary analysis of changes in conservation and development discourse and the development of a conservation-poverty timeline as part of the process of establishing the Poverty and Conservation Learning Group. Alessandra Giuliani is responsible for maintaining the Group's bibliographic database on which this review is based. The Poverty and Conservation Learning Group is currently supported by the Ford Foundation and Irish Aid.

\section{References}

Adams, W.M. (2004) Against Extinction. The Story of Conservation. Earthscan, London, UK.

A lcorn, J.B. (1993) Indigenous peoples and conservation. Conservation Biology, 7, 424-427.

Amazon Alliance (undated) Role of the Amazon Alliance. Amazon Alliance, Washington, DC, USA. Http://www.amazonalliance.org/ index.aspx?PBI=1907 [accessed 12 May 2008].

Anderson, D. \& Grove, R. (1987a) The scramble for Eden: past, present and future in African conservation. In Conservation in Africa: People, Policies and Practice (eds D. Anderson \& R. Grove), pp. 1-20. Cambridge University Press, Cambridge, UK.

Anderson, D. \& Grove, R. (eds) (1987b) Conservation in Africa: People, Policies and Practice. Cambridge University Press, Cambridge, UK.

Angelsen, A. \& Wunder, S. (2003) Exploring the Forest-Poverty Link: Key Concepts, Issues and Research Implications. CIFOR, Bogor, Indonesia.

Balasinorwala, T.K. \& Goyal, M. (2004) Participatory Conservation. Paradigm Shifts in International Policy. IUCN, Gland, Switzerland.

Batisse, M. (1982) The Biosphere Reserve: a tool for environmental conservation and management. Environmental Conservation, 9, 101-111.

Borgerhoff Mulder, M. \& Coppolillo, P. (2005) Conservation: Linking Ecology, Economics and Culture. Princeton University Press, Princeton, USA.

Brandon, K., Redford, K. \& Sanderson, S. (1998) Parks in Peril: People, Politics and Protected Areas. Island Press, Washington, DC, USA.

Bray, D.B. \& Anderson, A.B. (2005) Global Conservation, Nongovernmental Organizations, and Local Communities: Perspectives on Programs and Project Implementation in Latin America. Working Paper 1. Florida International University Institute for Sustainability Science in Latin America and the Caribbean, Miami, USA.

Brechin, S., Wilshusen, P.R., Fortwangler, C. \& West, P.C. (2001) Beyond the square wheel: towards a more comprehensive understanding of biodiversity conservation as a social and political process. Society and Natural Resources, 15, 41-64.

Brechin, S., Wilshusen, P.R., Fortwangler, C. \& West, P.C. (eds) (2003) Contested Nature: Promoting International Biodiversity Conservation with Social Justice in the Twenty-first Century. SUNY Press, Albany, USA.

Brockington, D. \& Igoe, J. (2006) Eviction for conservation: a global overview. Conservation \& Society, 4, 424-470.

Brockington, D., Igoe, J. \& Schmidt-Soltau, K. (2006) Conservation, human rights and poverty reduction. Conservation Biology, 20, 250-252.

Caldwell, K. (1954) The Bukavu Conference. Oryx, 2, 234-237.

Campbell, L.M. \& Vainio-Mattila, A. (2003) Participatory development and community-based conservation: opportunities missed for lessons learned? Human Ecology, 31, 417-437.

Castree, N. (2003) Bioprospecting: from theory to practice (and back again). Transactions of the Institute of British Geographers, 28, 35-55.

CEQ (1981) Global 2000 Report to The President. US Council on Environmental Quality, Washington, DC, USA.

Cernea, M. (2003) Biodiversity Conservation Versus Population Resettlement: Risks to Nature and Risks to People. Paper presented at The International Conference on Rural Livelihoods, Forests and Biodiversity, 19-23 May 2003, Bonn, Germany. 
Cernea, M.M. \& Schmidt-Soltau, K. (2006) Poverty risks and national parks: policy issues in conservation and resettlement. World Development, 34, 1808-1830.

Chambers, R. (1981) Rapid rural appraisal: rationale and repertoire. Public Administration and Development, 1, 95-106.

Chambers, R. (1983) Rural Development: Putting the Last First. Longman, New York, USA.

Chambers, R. (1987) Sustainable Livelihoods, Environment and Development: Putting Poor Rural People First. IDS Discussion Paper 240. Institute of Development Studies, Brighton, UK.

Chapin, M. (2004) A challenge to conservationists. World Watch, Nov/Dec, 17-31.

CHILD, B. (2003) Origins and efficacy of modern CBNRM practices in the Southern African region. In Local Communities, Equity and Conservation in Southern Africa (eds W. Whande, T. Kepe \& M. Murphree), pp. 33-39. Programme for Land and Agrarian Studies, University of the Western Cape, Cape Town, South Africa.

COICA (CoOrdinating Body for the Indigenous Organizations of the Amazon Basin) (1989) Two agendas on Amazon development. Cultural Survival Quarterly, 13, 75-78.

Colchester, M. (2003) Salvaging Nature: Indigenous Peoples, Protected Areas and Biodiversity Conservation. World Rainforest Movement and Forest Peoples Programme, Moreton-in-Marsh, UK.

Colchester, M. (2004) Conservation policy and indigenous peoples. Cultural Survival Quarterly, 28, 17-22.

Commission of the European Communities (2006) Halting the Loss of Biodiversity by 2010-and Beyond. Sustaining Ecosystem Services for Human Well-being. COM (2006) 216 Final. Commission of the European Communities, Brussels, Belgium.

Council of the European Union (2006) Conclusions of the Council of the Representatives of the Governments of the Member States Meeting within the Council on Biodiversity: The Message from Paris. Council of the European Union, Brussel, Belgium.

Cross, N. (ed.) (2003) Evidence for Hope: The Search for Sustainable Development. Earthscan, London, UK.

CURRY - LindahL, K. (1978) Background and development of international conservation organisations and their role in the future. Environmental Conservation, 5, 163-169.

Dasmann, R., Milton, J. \& Freeman, P. (1973) Ecological Principles for Economic Development. IUCN and the Conservation Foundation, Morges, Switzerland and Washington, DC, USA.

De Sherbinin, A. (2008) An assessment of infant mortality rates around protected areas in developing countries. Oryx, 42, $26-35$.

DEG (2006) A BOND Development and Environment Group (DEG) response to the UK Department for International Development White Paper 2006: Eliminating World Poverty: Making Governance Work for the Poor. British Overseas NGOs for Development, London, UK. Http://www.bond.org.uk/pubs/groups/ environment/deg_dfidpaper_06.doc [accessed 21 May 2008].

DFID (1997) Eliminating World Poverty: A Challenge for the 21st Century. White Paper on International Development. HMSO, London, UK.

DFID (Department for International Development), EC, UNDP (United Nations Development Programme) \& World Bank (2002) Linking Poverty Reduction and Environmental Management: Policy Challenges and Opportunities. World Bank, Washington, DC, USA.

Dowie, M. (2005) Conservation refugees: when protecting nature means kicking people out. Orion Magazine, November/December, $16-27$.

Ellis, F. \& BigGs, S. (2001) Evolving themes in rural development 1950s-200os. Development Policy Review, 19, 437-448.
Escoв A , A. (1995) Encountering Development: The Making and Unmaking of the Third World. Princeton University Press, Princeton, USA.

FORTWANGLER, C. (2003) The winding road: incorporating social justice and human rights into protected area policies. In Contested Nature: Promoting International Biodiversity with Social Justice in the Twenty-first Century (eds S. Brechin, P.R. Wilshusen, C. Fortwangler \& P. West), pp. 25-39. State University of New York Press, Albany, USA.

G8 (2007) Potsdam Initiative - Biological Diversity. G8 Environment Ministers Meeting, 15-17 March 2007, Potsdam, Germany. Http:// www.g-8.de/Content/EN/_Anlagen/2007-03-18-potsdamererklaerung-en,property=publicationFile.pdf [accessed 1 June 2007].

Goodland, R.J.A. (1982) Tribal Peoples and Economic Development: Human Ecologic Considerations. World Bank, Washington, DC, USA.

Government of Norway (2006) Norwegian Action Plan for Environment in Development Cooperation. Norwegian Ministry of Foreign Affairs, Oslo, Norway.

Griffiths, T. (2007) Seeing RED? Avoided Deforestation and the Rights of Indigenous Peoples and Local Communities. Forest Peoples Programme, Moreton-in-Marsh, UK.

Griffiths, T. \& Colchester, M. (2000) Indigenous Peoples, Forests and the World Bank: Policies and Practice. World Rainforest Movement, Moreton-in-Marsh, UK. Http://www.wrm. org.uy/actors/WB/IPreport.html [accessed 14 February 2007].

Grove, R. (1987) Early themes in African conservation: the Cape in the nineteenth century. In Conservation in Africa: People, Policies and Practice (eds D. Anderson \& R. Grove), pp. 21-39. Cambridge University Press, Cambridge, UK.

GuHA, R. (1999) Environmentalism: A Global History. AddisonWesley, New York, USA.

Holdgate, M. (1999) The Green Web: A Union for World Conservation. Earthscan, London, UK.

Horowitz, , J. \& O'Sullivan, , R. (2008) The Hidden Value of Bali: Why Saving the World's Rainforests is Good for the Climate and the US Economy. Http://news.mongabay.com/2008/0110avoided_deforestation.html [accessed 16 January 2008].

Hutton, J., Adams, W.M. \& Murombedzi, J. (2005) Back to the barriers? Changing narratives in biodiversity conservation. Forum for Development Studies, 2, 341-370.

IGOE, J. (2006) Measuring the costs and benefits of conservation to local communities. Journal of Ecological Anthropology, 10, $72-77$.

IIED (1994) Whose Eden? An Overview of Community Approaches to Wildife Management. International Institute for Environment and Development, London, UK.

IISD (2006) The Sustainable Development Timeline. International Institute for Sustainable Development, Winnipeg, Canada. Http:// www.iisd.org/pdf/2006/sd_timeline_2006.pdf [accessed 14 February 2007].

International Alliance (1992) International Alliance Charter. International Alliance of Indigenous and Tribal Peoples of the Tropical Forests, Chaing Mai, Thailand. Http://www. international-alliance.org/charter_eng.htm [accessed 14 February 2007].

IPCC (2007) Climate Change 2007: Climate Change Impacts, Adaptation and Vulnerability. Summary for Policymakers. Working Group II Contribution to the Intergovernmental Panel on Climate Change, Fourth Assessment Report. Intergovernmental Panel on Climate Change, Geneva, Switzerland. Http://www.ipcc.ch/pdf/ assessment-report/ar4/wg2/ar4-wg2-spm.pdf [accessed 12 November 2007]. 
IUCN (2003a) The Durban Accord. IUCN, Gland, Switzerland. Http://www.iucn.org/themes/wcpa/wpc2003/pdfs/outputs/wpc/ durbanaccord.pdf [accessed 14 February 2007].

IUCN (2003b) The Durban Action Plan. IUCN, Gland, Switzerland. Http://www.iucn.org/themes/wcpa/wpc2003/pdfs/outputs/wpc/ durbanactionplan.doc [accessed 14 February 2007].

IUCN (2006) The Message from Paris. IUCN Regional Office for Europe, Brussels, Belgium.

IUCN, UNEP \& WWF (1980) World Conservation Strategy: Living Resource Conservation for Sustainable Development. IUCN, Gland, Switzerland.

IUCN, UNEP \& WWF (1991) Caring for the Earth: A Strategy for Sustainable Living. Earthscan, London, UK.

Khare, A. \& Bray, D.B. (2004) Study of Critical New Forest Conservation Issues in the Global South. Ford Foundation, New York, USA.

Kiss, A. (1990) Living with Wildlife: Wildlife Resource Management with Local Participation in Africa. Technical Paper 130. World Bank, Washington, DC, USA.

Kramer, R.A., van Schaik, C.P. \& Johnson, J. (eds) (1997) The Last Stand: Protected Areas and the Defense of Tropical Biodiversity. Oxford University Press, New York, USA.

LiNDSAY, W.K. (1987) Integrating parks and pastoralists: some lessons from Amboseli. In Conservation in Africa: People, Policies and Practice (eds D. Anderson \& R. Grove), pp. 149-168. Cambridge University Press, Cambridge, UK.

Lockwood, M., Worboys, G. \& Kothari, A. (2006) Managing Protected Areas: A Global Guide. Earthscan, London, UK.

Maxwell, S. (1999) The Meaning and Measurement of Poverty. Poverty Briefing No. 3. Overseas Development Institute, London, UK.

McNeely, J.A. \& Miller, K.R. (eds) (1982) National Parks, Conservation and Development: The Role of Protected Areas in Sustaining Society. IUCN, Gland, Switzerland.

McShane, T.O. (2003) Protected areas and poverty - the linkages and how to address them. Policy Matters, 12, 52-53.

Millennium Ecosystem Assessment (2005) Ecosystems and Human Well-being: Biodiversity Synthesis. World Resources Institute, Washington, DC, USA.

Naryan, D., Patel, R., Schafft, K., Rademacher, A. \& KochSchulte, S. (2000) Voices of the Poor: Can Anyone Hear Us? World Bank, Washington, DC, USA.

Nasi, R. \& CUnningham, T. (2001) Sustainable Management of Non-timber Forest Resources: A Review with Recommendations for SBSTTA. Secretariat to the Convention on Biological Diversity, Montreal, Canada.

OAtes, J. (1999) Myth and Reality in the Rainforest: How Conservation Strategies are Failing in West Africa. University of California Press, Berkeley, USA.

OAtES, J.F. (2006) Conservation, development and poverty alleviation: time for a change in attitudes. In Gaining Ground: In Pursuit of Ecological Sustainability (ed. D. Lavigne), pp. 277-284. International Fund for Animal Welfare, Guelph, Canada.

OECD (1996) Shaping the 21st Century: The Contribution of Development Co-operation. Organization for Economic Cooperation and Development, Paris, France.

OECD (2006) Framework for Common Action Around Shared Goals. Organization for Economic Cooperation and Development, Paris, France.

Phillips, A. (2003) A modern paradigm. World Conservation Bulletin, 2, 6-7.

Poore, D. (1976) Ecological Principles for Development in Tropical Rainforests. IUCN, Morges, Switzerland.
Prescott-Allen, R. \& Prescott-Allen, C. (1982) What's Wildlife Worth? Economic Contributions of Wild Plants and Animals to Developing Countries. Earthscan, London, UK.

Rangarajan, M. \& Shahabuddin, G. (2006) Displacement and relocation from protected areas: towards a biological and historical synthesis. Conservation \& Society, 4, 359-378.

RAO, K. \& Geisler, C. (1990) The social consequences of protected areas development for resident populations. Society \& Natural Resources, 3, 19-32.

Redford, K. \& Sanderson, S. (2002) Contested Relationships Between Biodiversity Conservation and Poverty Alleviation. Paper presented at 13th Annual Meeting of the Society for Conservation Biology, 15-18 July 2002, University of Kent, Canterbury, UK.

Redford, K.H. (1990) The ecologically noble savage. Orion Nature Quarterly, 9, 24-29.

Redford, K.H. \& Fearn, E. (eds) (2007) Protected Areas and Human Displacement: A Conservation Perspective. Working Paper No. 29. Wildlife Conservation Society, New York, USA.

Redford, K.H. \& Stearman, A.M. (1993) On common ground? Response to Alcorn. Conservation Biology, 7, 427-428.

Redford, K.H., Levy, M.A., SAnderson, E.W. \& de Sherbinin, A. (2008) What is the role for conservation organizations in poverty alleviation in the world's wild places? Oryx, 32, 516-528.

Reid, H. \& Swiderska, K. (2008) Biodiversity, Climate Change and Poverty: Exploring the Links. IIED Briefing. International Institute for Environment and Development, London, UK.

Rietbergen, S., Bishop, J. \& Mainka, S. (2002) Ecosystem Conservation - A Neglected Tool for Poverty Reduction. WSSD Opinion Series. International Institute for Environment and Development, London, UK.

Ris T, G. (2002) The History of Development: From Western Origins to Global Faith. Zed Books, London, UK.

Robinson, J. (1993) The limits to caring: sustainable living and the loss of biodiversity. Conservation Biology, 7, 20-28.

Robinson, J. \& Bennett, E.L. (2002) Will alleviating poverty solve the bushmeat crisis? Oryx, 36, 332 .

Robinson, J. \& Redford, K. (2004) Jack of all trades, master of none: inherent contradictions among ICD approaches. In Getting Biodiversity Projects to Work: Towards More Effective Conservation and Development (eds T.O. McShane \& M. Wells), pp. 10-34. Columbia University Press, New York, USA.

Roe, D. \& Elliott, J. (2004a) Poverty reduction and biodiversity conservation: rebuilding the bridges. Oryx, 38, 137-139.

Roe, D. \& Elliott, J. (2004b) Meeting the MDGs: is conservation relevant? In The Millennium Development Goals and Conservation: Managing Nature's Wealth for Society's Health (ed. D. Roe), pp. 7-19. International Institute for Environment and Development, London, UK.

Roe, D., Reid, H., Vaughan, K., Brickell, E. \& Elliott, J. (2007) Climate, Carbon, Conservation and Communities. An IIED/WWF Briefing. International Institute for Environment and Development, London, UK.

Roe, D. \& Walpole, M. (in press) Whose Value Counts? Disentangling Biodiversity-Poverty Relationships. Proceedings of the ZSL Symposium on Tradeoffs in Conservation: Deciding What to Save. Blackwell Publishing, Oxford, UK.

Romero, C. \& Andrade, G.I. (2004) International conservation organizations and the fate of local tropical forest conservation initiatives. Conservation Biology, 18, 578-580.

SANDBrook, R. (1984) Opening the environmental debate. In The Environmental Crisis: A Handbook For All Friends of the Earth (ed. D. Wilson), pp. 11-21. Heinemann Educational Books, London, UK. 
SANDBROOK, R. (2003) Change that works, sometimes. In Evidence for Hope: The Search for Sustainable Development (ed. N. Cross), pp. 60-74. Earthscan, London, UK.

SAnderson, S. (2005) Poverty and conservation: the new century's "peasant question". World Development, 33, 323-332.

Sanderson, S. \& Redford, K. (2003) Contested relationships between biodiversity conservation and poverty alleviation. Oryx, $37,1-2$.

Satterthwaite, D. (2003) The Millennium Development Goals and Local Processes: Hitting the Target or Missing the Point? International Institute for Environment and Development, London, UK.

Scoones, I., Melny , M. \& Pretty, J. (1992) The Hidden Harvest: Wild Foods and Agricultural Systems: A Literature Review and Annotated Bibliography. International Institute for Environment and Development, London, UK.

Short, C. (2002) Bushmeat and Poverty. Speech by Clare Short, Secretary of State for International Development, at the UK Bushmeat Campaign Conference, Zoological Society of London, 28 May 2002. UK Department for International Development, London, UK. Http://www.dfid.gov.uk/pubs/files/bushmeatspeech-sos.pdf [accessed 14 February 2007].

Stern, N. (2006) The Economics of Climate Change: The Stern Review. Cambridge University Press, Cambridge, UK.

Stiglitz, J. (1998) Towards a New Paradigm for Development: Strategies, Policies, and Processes. 1998 Prebisch Lecture. UNCTAD, Geneva, Switzerland.

StRONG, M. (1977) The international community and the environment. Environmental Conservation, 4, 165-172.

S TRONG, M. (2003) Stockholm: the founding of IIED. In Evidence for Hope: The Search for Sustainable Development (ed. N. Cross), pp. 19-27. Earthscan, London, UK.

SwidersKa, K. (2006) Banishing the Biopirates: A New Approach to Protecting Traditional Knowledge. Gatekeeper Series No. 129. International Institute for Environment and Development, London, UK.

Tадвот, L. (1980) The world's conservation strategy. Environmental Conservation, 7, 259-268.

Terborgh, J. (1999) Requiem for Nature. Island Press, Washington, DC, USA.

Terborgh, J. (2004) Reflections of a scientist on the World Parks Congress. Conservation Biology, 18, 619-620.

United Nations (1992) The Convention on Biological Diversity. United Nations, New York, USA.

United NATIONs (2002a) Johannesburg Declaration on Sustainable Development. UN Department of Economic and Social Affairs, New York, USA.

United Nations (2002b) Johannesburg Plan of Implementation. UN Department of Economic and Social Affairs, New York, USA.

Upton, C., Ladle, R., Hulme, D., Jiang, T., Brockington, D. \& Adams, W.M. (2008) Are poverty and protected areas linked at a national scale? Oryx, 42, 19-25.

W alpole, M. (2006) The Case for Integrating Conservation and Human Needs. Fauna \& Flora International, Cambridge, UK [http://www.fauna-flora.org/docs/ffilivelihoodsconservation.pdf, accessed 27 March 2008].

WCED (World Commission on Environment and Development) (1987) Our Common Future: Report of the World Commission on Environment and Development. Oxford University Press, Oxford, UK.

West, P. \& Brechin, S. (1991) Resident Peoples and National Parks. University of Arizona Press, Tucson, USA.

West, P., Igoe, J. \& Brockington, D. (2006) Parks and peoples: the social impact of protected areas. Annual Review of Anthropology, 35, 251-277.

Western, D. \& Wright, M. (1994) Natural Connections: Perspectives in Community-Based Conservation. Island Press, Washington, DC, USA.

Wilkie, D.S., Morelli, G.A., Demmer, J., Starkey, M., Telfer, P. \& S TEIL, M. (2006) Parks and people: assessing the human welfare effects of establishing protected areas for biodiversity. Conservation Biology, 20, 247-249.

Wilshusen, P.R., Brechin, S., Fortwangler, C. \& West, P.C. (2001) Reinventing a square wheel: critique of a resurgent "protection paradigm" in international biodiversity conservation. Society and Natural Resources, 15, 17-40.

Wilshusen, P.R., Brechin, S., Fortwangler, C. \& West, P.C. (2003) Contested nature: conservation and development at the turn of the twenty-first century. In Contested Nature: Promoting International Biodiversity with Social Justice in the Twenty-First Century (eds S. Brechin, P.R. Wilshusen, C. Fortwangler \& P. West), pp. 1-22. State University of New York Press, Albany, USA.

WORLD BANK (2001) World Development Report 2000/2001: Attacking Poverty. World Bank, Washington, DC, USA.

World Resources Institute (2005) World Resources 2005: The Wealth of the Poor - Managing Ecosystems to Fight Poverty. UNEP/ UNDP/WRI/World Bank, Washington, DC, USA.

WorldWATch Institute (2005a) Readers' responses to "A challenge to conservationists". World Watch Magazine, 18(1), 5-20.

WORLDWATCH InSTITUTE (2005b) Readers' responses to "A challenge to conservationists" - additions. World Watch Magazine, 18(2). Http://www.worldwatch.org/node/1832 [accessed 20 February 2007].

\section{Biographical sketches}

Dilys Roe is a senior researcher in the Natural Resources Group of the International Institute for Environment and Development (IIED), London, UK, and a $\mathrm{PhD}$ candidate at the Durrell Institute for Conservation and Ecology, University of Kent at Canterbury, UK. The focus of her work at IIED is on the interactions between conservation and society, and her $\mathrm{PhD}$ is exploring the institutionalization of poverty reduction within conservation organizations. At IIED Dilys coordinates the Poverty and Conservation Learning Group. See http://www.povertyandconservation.info for more information on this group and for a full list of references on povertyconservation linkages. 